PRZEGLĄD RUSYCYSTYCZNY 2021, nr 2 (174)

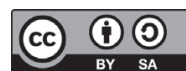

DOI 10.31261/pr.10306

\author{
JOLANTA LUBOCHA-KRUGLIK \\ Uniwersytet Śląski w Katowicach \\ iD http://orcid.org/0000-0001-8022-5901 \\ КАДИША НУРГАЛИ \\ Евразийский государственный университет им. Л. Н. Гумилева, Нур-Султан, Казахстан \\ (iD http://orcid.org/0000-0002-8178-2782
}

\title{
ПАРАТЕКСТЫ АВТОРА И ПЕРЕВОДЧИКА (НА МАТЕРИАЛЕ ПРОИЗВЕДЕНИЙ ВИКТОРА ПЕЛЕВИНА)
}

\begin{abstract}
TRANSLATOR'S PARATEXTS (BASED ON VIKTOR PIELEWIN'S NOVELS)
Paratext, a term coined by Gerard Genette, is used to describe elements functioning along with the main text, including, among others: forewords, epigraphs, translator's, and author's comments. Contemporary researchers are further developing the paratext theory formulated by Genette. Currently, the paratexts are being examined, taking into account the broadly understood extralinguistic context. The article predominantly focuses on the author's and the translator's paratexts. This study's research material consists of novels written by Victor Pelevin - one of the most famous Russian writers these days. Keywords: paratext, title, translation
\end{abstract}

Паратексты всегда пользовались вниманием представителей разных областей науки. Этот интерес к ним можно объяснить в частности тем, что трактовка паратекстов в характере промежуточных текстовых инстанций между текстом и реальностью дает возможность их очень широкой интерпретации. В настоящее время наблюдается возрастающий интерес к изучению паратекста вместе с широко понимаемым экстралингвистическим контекстом. Особое внимание уделяется также функциональной значимости паратекстов автора и переводчика для успешности рецепции произведения. Помимо прочего, в случае переводческих паратекстов предметом исследований становится также ассимиляция данного текста в новом культурном пространстве. 
Термин «паратекст» ввел, как известно, французский литературовед Жерар Женетт в 1987 г. в работе Seuils ${ }^{1}$. Паратекст в понимании ученого «is what enables a text to become a book and to be offered as such to its readers and, more generally, to the public» ${ }^{2}$, т.e. то, что позволяет тексту превратиться в книгу и в качестве таковой предложить его читателю и, в более общем смысле, широкому кругу адресатов. Женетт называет паратексты «порогами литературного текста» (англ. treshold) и причисляет к ним «полиграфическое оформление книги, имя автора, заглавие, посвящение, эпиграф, примечания, интервью и беседы с автором, более или менее просчитанные откровения и прочие „предуведомления”, размещаемые обычно на спинке обложки» ${ }^{3}$. Паратексты трактуются также как одно из значимых средств убеждения и оценки, которые прямо или косвенно, эксплицитно или скрыто воздействуют на адресата и способствуют определенному восприятию произведения как до его прочтения, так и после. Исследуя паратекст, Женетт впервые высказывает мысль о приравнении перевода к паратексту. Ученый полагает, что переводпаратекст выполняет функцию комментария к основному тексту $^{4}$. Однако, в работах современных исследователей эта идея не нашла развития - чаще наряду с понятием паратекст применяется понятие параперевод 5 .

Материалом для анализа в настоящей статье послужили произведения Виктора Пелевина, которого литературный критик - Егор Беликов - немного иронически - называет «главным писателем современной России» ${ }^{6}$. Несмотря на эту иронию, сомнению не подлежит факт, что в настоящее время Пелевин яв-

1 В настоящей статье мы пользуемся английским переводом этой книги: G. Genette, Paratexts: Tresholds of Interpretation, пер. J. Lewin, Cambridge University Press, Cambridge 1997 [электронная версия 2001 г.].

2 Там же, с. 1.

3 Ж. Женетт, Посвящения. Перевод, вступительная заметка и примечания Л. Семеновой // В.В. Иванов (отв. ред.), Антропология культуры. Выпуск 2, Вердана, Москва 2004, с. 187.

4 G. Genette, Paratexts..., c. 405.

5 См., напр., A.G. Bardaji, P. Orero, S. R. Esteva (ред.), Translation Peripheries: Paratextual Elements in Translation, Peter Lang, Frankfurt an Main, 2012. Паратекст, в трактовке авторов работ, входящих в данную монографию, является локальным порождением и неотделим от культурного и социальнополитического контекста.

6 Е. Беликов, Масоны против чекистов. Книга, ради которой «убили» Пелевина, https://life.ru/p/902662 (10.10.2020). 
ляется писателем, популярность которого давно уже вышла за границы России. Об этом свидетельствует и ряд престижных российских и зарубежных премий, которыми удостоено творчество писателя: он является лауреатом Малой Букеровской премии, получил ряд престижных премий по фантастике: «Золотой шар», «Великое Кольцо», «Бронзовая улитка», «Интерпресскон», «Странник» и др.; его проза попала в «шорт-лист» «Independent Foreign Fiction Prize» - английской премии за переводную литературу. «French Magazine» включил Виктора Пелевина в список 1000 самых значимых современных деятелей мировой культуры.

Большинство критиков причисляет его к постмодернистской школе, но есть и такие, которые считают, что творчество Пелевина настолько разнообразно, что не укладывается в строгие рамки одного только направления. И действительно - жанровую структуру прозы Виктора Пелевина можно определить как поливариантную. В интертекстуальном пространстве его произведений важную роль играют авторские паратексты, аллюзии, многочисленные цитаты (явные и скрытые), говорящие имена собственные и многомерные заглавия. Писатель успешно применяет огромный семантический потенциал библейских, мифологических, исторических, литературных и публицистических текстов, использует постмодернистский прием палимпсеста. В результате перед читателем появляется многослойный текст, представляющий собой сложную закодированную структуру, которая, с одной стороны, нуждается в расшифровке, с другой же, как любая загадка, прельщает. Его тексты состоят из множества фрагментов, которые, соединенные друг с другом сложной системой перекрестных ссылок, образуют один большой гипертекст.

Насыщенность текста этими ссылками, языковые и семиотические игры с читателем, непростой диалог с традицией являются причиной того, что тексты Пелевина бывают сложными и для россиян. Еще бо́льшие проблемы могут возникнуть при изменении культурной перспективы.

Паратексты, сопровождающие перевод, являются, как правило, более сложными, чем паратексты, встречаемые в одноязычной коммуникации. Столкновение как минимум двух культур способствует дифференциации их типов и функций. 
Одним из значимых компонентов в структуре паратекстов является фамилия автора произведения. Вопреки распространенному суждению о том, что знакомство с произведением начинается с заголовка (хотя, естественно, бывает и так), мы считаем, что в некоторых случаях она важнее его. Для более подготовленных читателей именно фамилия автора является первым сигналом принадлежности произведения к определенному литературному направлению или жанру. Фамилия Пелевина стала уже фирменным знаком, который гарантирует особую творческую манеру письма, пребывание в необычном, порой - фантастическом мире. Сам писатель создает вокруг себя атмосферу некой тайны - редко дает интервью, еще реже позволяет себя фотографировать. Тем более в качестве элемента продуманной маркетинговой стратегии следует воспринимать некоторые обложки его книг, на которых на первой странице - рядом с написанной фамилией и заглавием - появляется его фотография7.

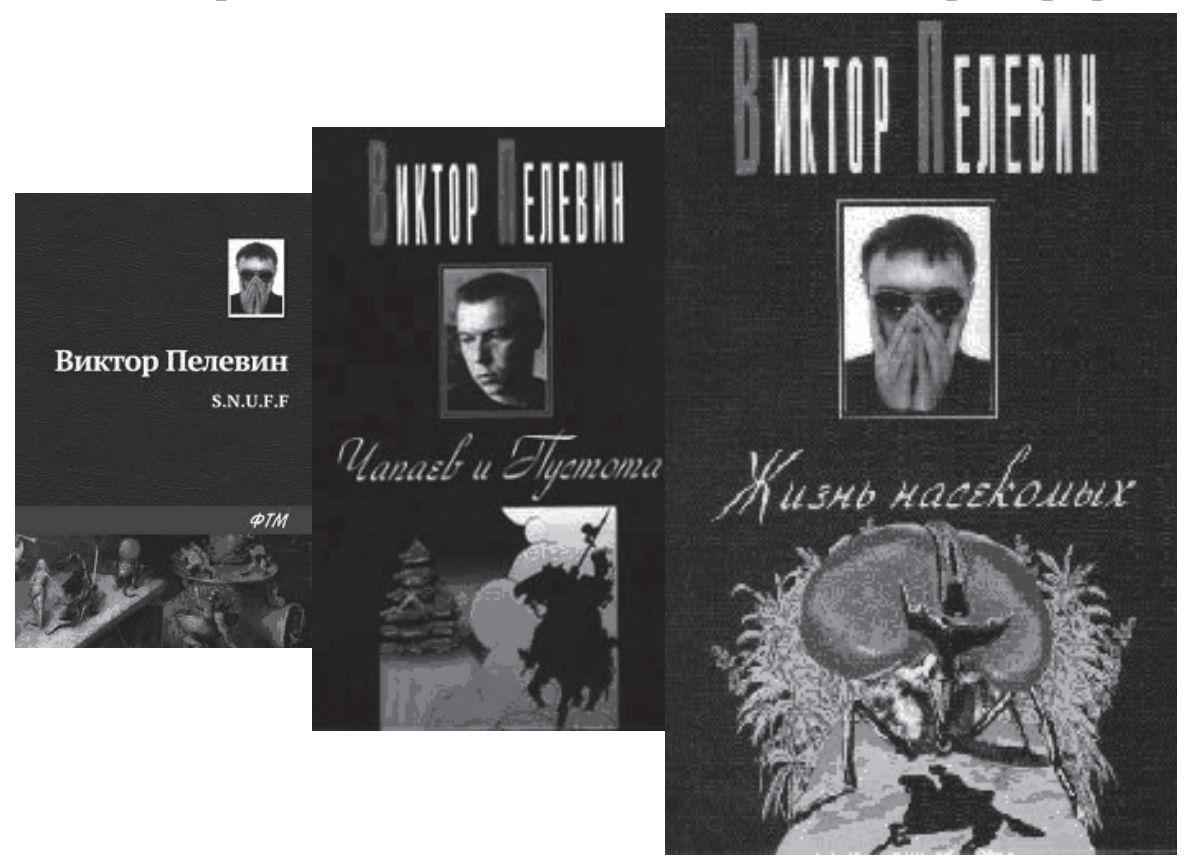

Во многих изданиях, однако, фотография помещена на задней сторонке обложки, рядом с аннотацией, что является уже типичным издательским решением.

7 Существуют, естественно, и издания без фотографии писателя. 
Пелевин известен также польским читателям, хотя конечно в меньшей степени, чем русским. В связи с этим польские издания выпускаются, как правило, в другом оформлении. Если на обложке польских изданий появляется фотография Пелевина, то обычно на задней сторонке обложки - рядом с аннотацией. Аннотация содержит основные факты из жизни писателя, представляет краткое содержание произведения либо какой-то его интересный фрагмент. В польских аннотациях часто появляется также информация, заимствованная из различных источников - радио-, телепередач и отзывов литературных критиков или писателей. Как это всегда бывает в случае переводной литературы - обязательна здесь информация о том, представителем какой страны является автор.

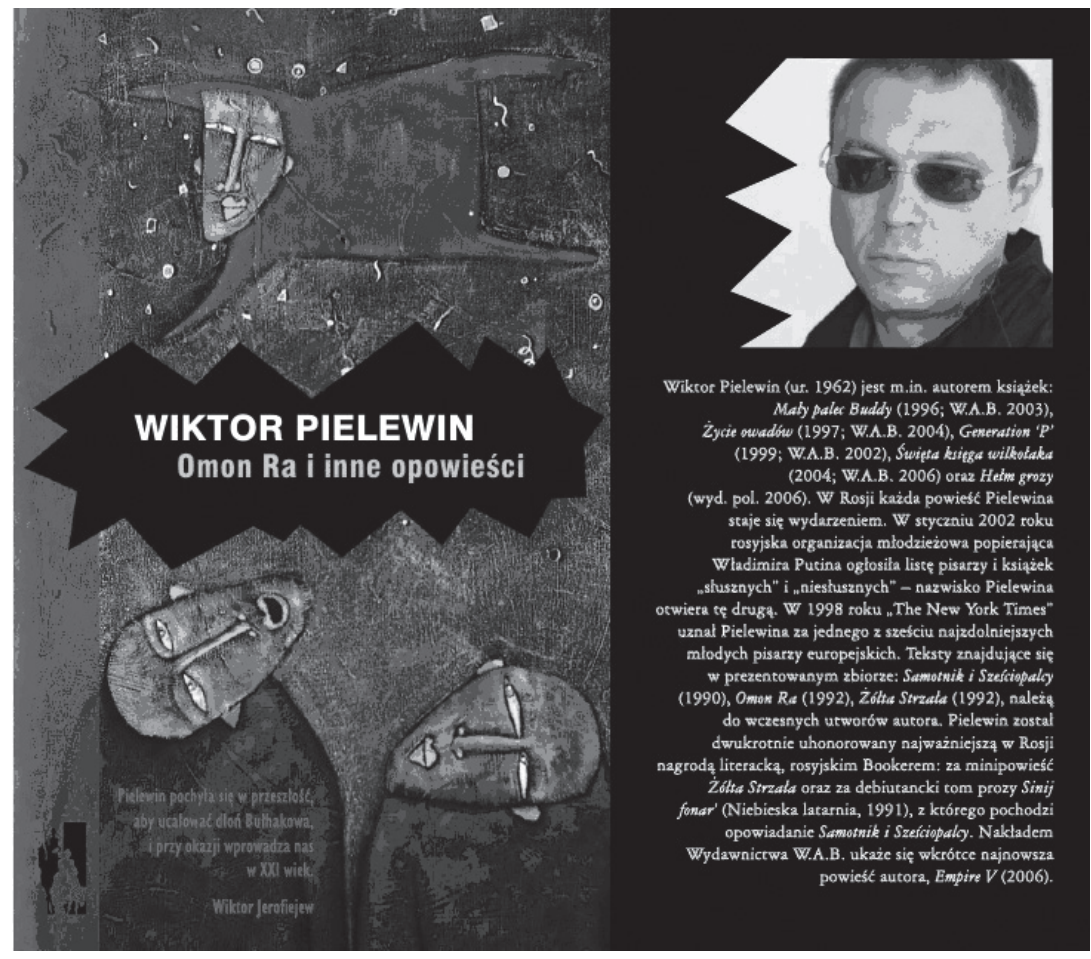

Паратексты не могут существовать без основного текста (так же как перевод не существует без оригинала). Это относится даже к таким случаям, когда текст не доступен материально, а появляется лишь в форме заглавия либо упоминания о нем, как в случае ссылок на античные тесты, не сохранившиеся до на- 
ших времен, или же использования литературного приема писать о книгах, которые не существуют.

Как уже отмечалось, паратексты в переведенных произведениях обладают особым статусом. Переведенное произведение остается всегда творением своего автора, но оно функционирует по-другому. Первым сигналом этого является предтекстовая единица паратекста, т.е. заглавие - не всегда измененное, но (почти) всегда на другом языке. Заглавие, как известно, обладает своей автономией, одновременно же является неотъемлемой частью произведения и, как замечает Станислав Гайда, высказыванием о нем: «Заглавие называет текст, но помимо этого является также рамочным метатекстовым высказыванием, т.е. о тексте в тексте» ${ }^{8}$. При восприятии любого из произведений Пелевина уже в момент знакомства с его заглавием важными оказываются фоновые знания читателя, так как почти всем его заглавиям присущи скрытые смыслы. Интересным с этой точки зрения является заглавие Empire $V$ с подзаглавием Повесть о настоящем сверхчеловеке, в котором поясняется и уточняется тема основного заглавия. Это заглавие типично для Пелевина - оно многозначно и погружено во многих контекстах. Можно его воспринять, во-первых, как историко-политическую аллюзию, что обусловлено сюжетом, повествующем об империи, построенной вампирами. Во-вторых, это заглавие относится также к концепции, сформулированной монахом Филофеем, согласно которой после падения Рима и Константинополя третьим Римом должна быть Москва. Четвертый Рим - это Советский Союз, пятый же - существует сейчас и им является капиталистическая Россия. Но на этом интерпретация не заканчивается - это заглавие дает и другие возможности прочтения, отсылая, например, к роману Александра Проханова Симфония Пятой импеpuu, в частности же к ее английскому переводу. Для польского читателя все эти ссылки не понятны, не только потому, что произведение Проханова не переведено на польский. Непонятная здесь также мистика русской истории, о которой идет в нем речь. Польский читатель вряд ли сможет уловить соотнесение данного заглавия с романом Сергея Минаева Повесть о ненастоящем человеке, который, правда, переведен на польский язык, но не пользуется особой популярностью. Уловимой зато может быть

8 S. Gajda, Społeczne determinacje nazw własnych tekstów (tytutów), „Socjolingwistyka" 1987 , № 6 , c. 83 . 
ссылка на книгу Бориса Полевого Повесть о настоящем человеке, которая для представителей старшего поколения была книгой обязательного чтения. Интересующее нас здесь заглавие переводится автором на русский язык как Ампир $B$. В результате перестановки буквы $B$ перед словом ампир получаем слово вамnup. Такой прием предоставляет возможность вступить в диалог с многочисленными текстами о вампирах (Дракула Брэма Стокера; Интервъю с вампиром Энн Райс; Сумеречная Сага Стефани Майер и многими др.). Польский перевод этого заглавия - Empire $V$, однако, лишен такой многозначности, перестановка букв с целью образовать нужное здесь слово не получается.

В истории измененных заглавий внимания заслуживает также роман Чапаев и Пустота, построенный Пелевиным на реминисценциях, известных в советской и российской действительности. В массовом сознании россиян Чапаев давно функционирует не как герой отечественной войны, а прежде всего как персонаж анекдотов. Знание этого факта должно порождать определенные коннотации. Вторая часть заглавия относится к другому герою - Петру Пустоте, а пустота ведь - это одно из важнейших понятий постмодернизма. В польском переводе данный роман известен под заглавием Maty palec Buddy (Мизинец Будды), как подчеркивается, с согласия автора ${ }^{9}$. Изменение заглавия может быть, конечно, продиктовано разными причинами и это вполне приемлемо. Тем не менее, трудно не заметить, что читатель перевода теряет очень много. Оригинальное заглавие содержит ведь несколько закодированных смыслов - известные фамилии, ссылку на одноименный роман Фурманова и фильм под таким же заглавием.

Многозначным является также заглавие Любовъ $к$ трем цукербринам. Для русского читателя некоторые интертекстуальные ссылки, например, связь с оперой Сергея Прокофьева Любовь в трем апельсинам, видны сразу. Языковая игра строится здесь также на основании фонетического сходства слов цукербрин и апельсин. Такого подобия нет в польском языке, в котором заглавие оперы Прокофьева переведено как Miłość do trzech pomarańczy. Помимо прочего, в русском заглавии наблюдаем еще одно интересное явление. Слово «цукербрин» обра-

9 В США эта книга тоже известна под заглавием Buddha's Little Finger (в основном благодаря экранизации), в Великобритании же как Clay Machine Gun. 
зовано путем контаминации двух фамилий - Цукерберг (Mark Zuckerberg - основатель Фейсбука) и Брин (Sergey Brin - один из создателей Google). Правильное восприятие этой ссылки не зависит от национальной принадлежности; оно доступно только тем, кто эти фамилии знает.

Перейдем сейчас к другому существенному элементу паратекста - оглавлению, прагматическая цель которого сводится к передаче информации о содержании произведения через названия его глав. Оглавление либо предшествует основному тексту, либо помещается в конце книги. Пелевин использует обе эти возможности, хотя отдает предпочтение второй. Благодаря помещению содержания в конце книги читатель может восстановить в памяти представленные в тексте события, переосмыслить их и, в конечном итоге, проникнуть в авторский замысел (это не относится, конечно, к произведениям, в которых вместо содержания предоставляются только цифры, указывающие на очередность глав). Такую же возможность имеет и читатель переведенного текста. Однако, что типично для Пелевина, есть содержания, которые выходят за рамки такой интерпретации. В качестве примера приведем здесь его аллегорическую повесть Желтая стрела, в которой речь идет о поезде, идущим в никуда и в никогда. Внимания заслуживает здесь композиционное членение текста, на которое обращаем внимание уже на первой странице: нумерация глав идет в обратном порядке - от двенадцати до нуля. Этот прием повторяет польская переводчица Эва Роевска-Олеярчук, которая, похоже как автор, не применяет никаких комментариев, разъясняющих замысел автора. При этом оглавления как такового в повести нет. Это обусловлено, с одной стороны, тем, что Желтая стрела входит в состав сборника (в польском переводе тоже ${ }^{10}$ ), который имеет свое оглавление, с другой же - появление в качестве названий глав с 12 до о несомненно нарушило бы художественный эффект саспенса.

В общем, после просмотра оглавлений пелевинских произведений, можно прийти к выводу, что чаще всего они не готовят читателя к интерпретации, содержат лишь информацию о количестве глав или частей. Если же какая-то информация появляется, то она, как правило, суха и лаконична.

${ }^{10}$ W. Pielewin, Omon Ra i inne opowieści, nер. E. Rojewska-Olejarczuk, W.A.B., Warszawa 2007. 
Следующим важным элементом паратекста является предисловие, которое формально должно предшествовать основному тексту. Авторские паратексты Виктора Пелевина содержат, как правило, не только предисловие, но и эпиграфы. Согласно Женетту, эпиграфы могут служить комментарием к названию текста, подчеркивать его главную тематическую составляющую, представлять собой цитируемый текст или, наконец, выполнять функцию ключевого слова, необходимого для понимания исторических, культурных и биографического контекстов, связанных с автором ${ }^{11}$. Эпиграфы обозначены обычно шрифтом меньшего кегля, часто выделительным, например, курсивом. Если в эпиграфе дается иностранный текст с переводом, то их набирают разными начертаниями шрифта (часто основной текст курсивом, а перевод - прямым). Почти всегда имеется ссылка на источник.

Пелевинские эпиграфы следует трактовать как своего рода ключ, который может помочь читателю проникнуть глубже в содержание и уловить имплицитную информацию. Роман Чапаев и Пустота (Maty palec Buddy), например, начинается эпиграфом (точнее - квазиэпиграфом), придуманным самим Пелевиным, но приписанным им Чингиз Хану:

Глядя на лошадиные морды и лииа людей,

На безбрежный живой поток, поднятый

Моей волей и мчашийся в никуда по багровой

Закатной степи, я часто думаю:

Где Я в этом потоке?

Чингиз Хан

Этот эпиграф также представлен польской переводчицей этой книги - Хенрикой Бронятовской:

Patrzac na zrodzony moja

Wola bezkresny żywy potok

Końskich pysków i ludzkich twarzy,

Mknacy donikad po szkarłatnym

O zachodzie stepie, często pytam siebie:

Gdzie jestem Ja w tym potoku?

Czyngis-chan

${ }^{11}$ G. Genette, Paratexts..., c. 145-149. 
Обнаружить сразу, что это не настоящая цитата, практически невозможно. Примененные в нем слова звучат правдоподобно, так как речь идет здесь о руководстве массами людей, о конях, т.е. о том, что ассоциируется с этим полководцем. Одновременно буквальное восприятие данного квазиэпиграфа затрудняет выявление его более глубокого, философского смысла, т.е. отнесения к пространству пустоты. Помимо прочего, он служит также средством организации некой метафизической географии - подготавливает читателя к появлению в тексте внутренней Монголии - мистического места внутри тех, кто видит пустоту.

После этого эпиграфа в произведении помещается фиктивное предисловие, которое приписывается Пелевиным тибетскому ламе «Урган Джамбон Тулку VII - Председателю Буддийского Фронта Полного и Окончательного освобождения (ПОО (б))» ${ }^{12}$. Оно представляет собой критический отзыв на роман Чапаев и Пустота. Примененная здесь конвенция сосредоточивает внимание на процессе создания произведения, так как сразу находим здесь разъяснение, что существует несколько вариантов заглавия:

И последнее. Мы изменили название оригинального текста (он озаглавлен «Василий Чапаев») именно во избежсание путаниць с распространенной подделкой. Название «Чапаев и Пустота» выбрано как наиболее простое и несугzестивное, хотя редактор предлагал два других варианта — «Сад расходящихся Петек» и «Черный бублик».

В связи с изменением заглавия в польском переводе наблюдаются соответствующие изменения, смысл которых, однако, уловить польскому читателю будет сложно:

I na koniec. Zmieniliśmy tytuł oryginalnego tekstu (Wasilij Czapajew) właśnie po to, by uniknąc pomylenia go z wiadomym falsyfikatem. Tytuł Maty palec Buddy wybrany został jako najprostszy i mało sugestywny, chociaż redaktor proponował warianty: Ogród o rozwidlających się Pietkach i Czarny bajgiel ${ }^{13}$.

Разница в записи приведенного выше фрагмента оригинала и его польского перевода не случайна. В оригинальном произведении это предисловие сразу выделяется графически - оно записано курсивом, благодаря чему отличается от основного текста произведения. В польском переводе такого выделения

${ }_{12}$ В. Пелевин, Чапаев и пустота. Желтая стрела, Вагриус, Москва 2001, с. 9. ${ }^{13}$ W. Pielewin, Mały palec Buddy, пер. H. Broniatowska, W.A.B, Warszawa 2007. 
нет - все, за исключением заглавий, которые здесь появляются, записано простым шрифтом. Такое решение переводчицы не до конца оправдано. Во-первых, оно недостаточно выделяет текст, который хотел выделить сам автор, во-вторых, польский читатель может воспринять это предисловие сразу как основной текст. Заканчивается это предисловие в оригинале одной из самых известных в буддизме мантр, особенно характерных для тибетского буддизма, записанной русским алфавитом, - «Ом мани падме хум ${ }^{14}$. Польская переводчица же выбрала другую мантру - Праджня-парамиты - одну из самых известных первоисточников буддизма Махаяны ${ }^{15}$, которая не ассоциируется с Далай-Ламой, как это наблюдаем в тексте оригинала.

Похожие авторские приемы применяет Виктор Пелевин и в других своих произведениях. В романе Бэтман Аполло, например, находим цитату, которую Пелевин подписывает выделенным жирным шрифтом именем графа Дракулы:

В жизни вампира есть тайная отрада и тихое счастье.

Они в том, что цивилизационные стандарты либерального

гуманизма более не являются для него обязательными.

Граф Дракула

Такой же прием повторяет Эва Роевска-Олеярчук, которая фамилию графа-вампира выделяет с помощью прописных букв:

W życiu wampira sa chwile skrywanej

ostody i cichego szczęścia.

Biora się one stą, że nie obwiąuja go już standardy cywilizacyjne

liberalnego humanizmu.

HRABIA DRACULA

Существенным элементом пелевинского текста являются также иронические (иногда даже саркастические) авторские пара-

${ }^{14}$ Далай-Лама XIV говорил про сочетание слов «Ом мани падме хум», что оно символизирует чистоту тела, речи и ума Будды, http://o-buddizme.ru/ praktiki-i-meditaciya/om-mani-padme-khum (15.10.2020).

${ }^{15}$ В русс. переводе - Сутра сердца совершенной мудрости. Сутра Сердца Праджня-парамиты является одной из наиболее популярных и почитаемых сутр дальневосточной Махаяны, особенно в школе Чань (Дзэн). Имя Праджня-парамиты (Премудрости) также носит женщина-бодхисаттва, являющаяся феноменальным воплощением совершенной мудрости, http://zenkaisen.ru/zen-teaching/buddism-zen-sutry/sutra-serdca-zen/ (15.10.2020). 
тексты в виде предупреждений, которые можно воспринимать в качестве игрового начала. Текст такого типа (выделенный в оригинале жирным шрифтом) находим, например, в романах: Бетман Аполло:

Предупреждение:

книга содержит элементы живого разговорного русского языка (менее о, о16 \% текста). Могут быть задеты сексуалыные, политические и религиозные чувства читательницы, а также ее шизофренические и параноидальные комплексы. Автор не ставит такой цели и не несет ответственности за эффекты, возникающие в уме «Б» во время выработки агрегата «М5» ${ }^{16}$.

\section{(в польском переводе):}

Ostrzeżenie

Książka zawiera elementy żywego potocznego języka rosyjskiego (niespełna 0,016\% tekstu). Może urazić seksualne, polityczne i religijne uczucia czytelniczki oraz pobudzić jej schizofreniczne i paranoidalne kompleksy. Autor nie stawia sobie takiego celu i nie ponosi odpowiedzialności za efekty powstające $\mathrm{w}$ umyśle B podczas produkcji agregatu M5 ${ }^{17}$.

\section{и Ананасная вода для прекрасной дамы:}

Автор не обязательно разделяет религиозные, метафизические, политические, эстетические, национальные, фармакологические и прочие оценки и мнения, высказываемые персонажами книги, ее лирическими героями и фигурами рассказчиков ${ }^{18}$.

(польский перевод - Napój ananasowy dla pięknej damy):

Autor niekoniecznie podziela religijne, Metafizyczne, polityczne, estetyczne, Narodowościowe, farmakologiczne I tym podobne oceny i opinie, wypowiadane Przez postacie, bohaterów lirycznych oraz narratorów niniejszej książki ${ }^{19}$.

Авторская позиция Пелевина в этих текстовых элементах это позиция его «вненаходимости» по отношению ко всему, что он описывает.

${ }^{16}$ В. Пелевин, Бэтман Аполло, Эксмо, Москва 2013.

${ }^{17}$ W. Pielewin, Batman Apollo, пер. E. Rojewska-Olejarczuk. Wydawnictwo Literackie, Warszawa 2014.

${ }_{18}^{18}$ В. Пелевин, Ананасная вода для прекрасной дамы. Эксмо, Москва 2010.

${ }^{19}$ W. Pielewin, Napój ananasowy dla pięknej damy, пер. E. Rojewska-Olejarczuk, W.A.B., Warszawa 2011. 
Кроме паратекстов Пелевина есть еще паратексты издателя, которые дают дополнительные характеристики, напр.: Empire $V$ - повесть о настоящем сверхчеловеке (поль. перевод: Opowieść o prawdziwym nadczłowieku)

Иногда такие дополнительные характеристики даны только в польских переводах. Так, например, в книге Napój ananasowy dla pięknej damy появляется подзаглавие WOJN@ I ŚWIAT, в Mały palec Buddy - Powieść z przedmowa Urgana Dżambona Tulku; B Batman Apollo - NADCZŁOWIEK - TO BRZMI SUPERDUMNIE.

Они помещены, как правило, на титульных листах после заглавия, рядом с фамилией автора, переводчика и наименованием издательства.

В тексте перевода находим также элемент, которого никогда нет в оригинальном произведении, т.е. фамилию переводчика, записанную, как правило, на титульном листе мелким шрифтом. Среди польских переводов, которые были предметом нашего анализа, мы нашли лишь одно исключение от этого правила. В переводах, выполненных Александром Яновским для издательства Псыхоскок (Psychoskok), его фамилия помещается на лицевой стороне обложки рядом с фамилией автора. Такая позиция фамилии переводчика - хотя и редкая - может быть сигналом растущего интереса к личности переводчика, роль которого трудно ведь переоценить. Именно он в процессе осмысления перевода разъясняет с помощью доступных средств скрытые смыслы произведения. Дмитрий Бузаджи в статье Переводчик прозрачный и непрозрачный замечает, что:

Уже тот факт, что переводчик раз за разом выбирает некий вариант из множества возможных, и что разные переводчики никогда не переведут более или менее длинный текст полностью одинаково, свидетельствует о том, что в переводе всегда так или иначе отражается его создатель ${ }^{20}$.

Похожее мнение по поводу прозрачности переводчика высказывает Лоуренс Венути, который эту прозрачность (translator’s invisibility) считает иллюзией и пишет, что она является результатом неосознанности читателем того, что он имеет дело с переводом. Именно поэтому читатель не замечает переводчика,

${ }^{20}$ Д.М. Бузаджи, Переводчик прозрачный и непрозрачный, «Мосты» 2009, № 2 (22), c. 31. 
стоящего за текстом. Чем лучше перевод, тем более прозрачный переводчик ${ }^{21}$.

Помимо прочего, очевидно также то, что переводы часто нуждаются в критическом комментарии, в выражении мнения, в уточнении смыслов. Тем не менее среди всех типов паратекстов, существующих в художественных текстах, примечания переводчика в наибольшей степени подвергаются стереотипно негативному восприятию. О них можно услышать такие резкие замечания, как «позор переводчика», «признание собственного бессилия», «проявление некомпетентности» и т.д. В настоящее время отношение к ним немного изменилось. Дополнительная внетекстовая информация воспринимается часто как возможность полностью понять все нюансы текста, обнаружить интертекстуальные связи и узнать что-то новое. На дифференциацию примечаний переводчика оказывают влияние как жанр текста, так и более или менее определенный адресат перевода. На этот факт обращает внимание Ута Хрехорович, которая считает, что можно одобрить появление примечаний в текстах так называемой «общей литературы», т.е. во всякого рода эссе, в произведениях литературы факта, в исторических текстах и т.д., но их в принципе не должно быть вообще в произведениях художественной литературы ${ }^{22}$. Этот подход объясняется в частности тем, что в художественном тексте примечания переводчика могут мешать восприятию текста, нарушая плавный ход мысли. Такая позиция по отношению к примечаниям не является, конечно, обособленной. Однако, появляются и другие мнения, которые обращают внимание на тот факт, что надо все-таки сохранить некий компромисс, т.е. признать необходимость появления в тексте перевода некоторого количества примечаний ${ }^{2}$. Решение применять или не применять примечания может зависеть от общей переводческой стратегии. Если переводчик придерживается постулата о незаметности своего посредничества в переводческом процессе, тогда должен стараться создать на целевом языке текст, который

${ }^{21}$ L. Venuti, The Translator's Invisibility. A history of Translation, Routledge, London-New York 1995, c. 1-2.

${ }^{22}$ U. Hrehorowicz, Przypisy thumacza: to be or not to be // M. Filipowicz-Rudek, J. Konieczna-Twardzikowa, M. Stoch (ред.), Między oryginatem a przekładem 3: Czy zawód thumacza jest w pogardzie, Universitas, Kraków 1997, c. 110-111.

${ }^{23}$ См. шире об этом: E. Skibińska, O przypisach tłumacza // E. Skibińska (ред.), Przypisy thumacza. Wydawnictwo Uniwersytetu Wrocławskiego, Wrocław-Kraków, 2009, c. 11. 
будет читаться как текст оригинала. Если же переводчик примет решение о применении стратегии не скрывать своего присутствия в тексте - может показать текст во всей его чуждости и своеобразии.

В польских переводах произведений Виктора Пелевина наблюдаем разные стратегии. Александер Яновски использует примечания экономно, но тем не менее и так пытается передать польскому читателю больше знаний, чем получает читатель оригинала. После фамилии Damian-Landu Damilola Karpow, например, он дает сноску и объясняет: «Dziesięcioletni Damilola Taylor, urodzony w Nigerii, zmarł w Londynie w wyniku zadanych mu przez chuliganów ran kłutych, co stało się powodem głośnego procesu sądowego» ${ }^{24}$ или после фамилии Joschka Rudel - «Hans Ulrich Rudel był najbardziej utytułowanym asem hitlerowskiego lotnictwa szturmowegо» ${ }^{25}$; а после слов « ̇̇ycie jest zbyt krótkie. I słodkich kropli miodu na swej drodze nie napotkasz zbyt wiele» ${ }^{26}-$ пишет: "Trawestacja tekstu Okudżawy». Необходимость в таких пояснениях, как нам кажется, не существует, так как данный тип знаний при желании может приобрести сам читатель. Похожее замечание можно отнести к Эве Роевской-Олеярчук, которая в некоторых произведениях применяет примечания в действительно большом количестве. Имеем здесь в виду, например, ее переводы книг Generation П и Xpyстальный мир:

\section{Главный текст перевода:}

Jest to właściwie metoda Gurdżijewa* - tłumaczył Tatarskiemu. - Nawiązuje do tak zwanej drogi przebiegłego człowieka!27

Примечание переводчика: Metoda autopsychoterapii.

Или:

И еще было написано, что самое близкое понятие, которое существует в современной русской культуре, - это детская идиома „Гамовер”. От английского „Game Over» ${ }^{28}$.

${ }^{24}$ W. Pielewin, S.N.U.F.F, пер. A. Janowski, Psychoskok, Konin 2018.

25 Там же, с.10.

${ }^{26}$ Там же, с. 18.

${ }^{27}$ W. Pielewin, Generation P, пер. E. Rojewska-Olejarczuk, W.A.B., Warszawa 2002, c. 168.

${ }^{28}$ Там же, с. 278. 
Главный текст перевода:

Było tam również napisane, że najbliższe temu pojęcie, istniejące we współczesnej rosyjskiej kulturze, to młodzieżowe określenie „gamowier”*. Od angielskiego: game over ${ }^{29}$.

Примечание переводчика: «Nieprzetłumaczalna gra słów: gam - od wulg. gamak - homoseksualista, i Wier - od Wiera wiara; połączenie utworzone przez analogię do słowa starowier staroobrzędowiec».

Паратексты Роевской-Олеярчук представляют собой и комментарии к языковым элементам текста, и объяснения реалий. Это также ссылки на другие произведения и элементы так называемой третьей культуры. В других ее переводах (например, Batman Apollo), однако, количество примечаний незначительно.

Учитывая вышесказанное, можно прийти к выводу, что при анализе примечаний переводчика следует анализировать не только общую стратегию и связанные с ней технические параметры, но возможно и его личностные характеристики - переводческий опыт, знания, собственное творчество и др. Всякие обобщения в этом плане, по нашему мнению, невозможны и не оправданы.

Подытоживая же наши размышления над паратекстами в произведениях Виктора Пелевина - их функциями и дифференциацией - можно сказать, что это тема, которая не может быть подробно обсуждена в пределах одной только статьи. Практически каждое из произведений Виктора Пелевина в сопоставлении с его переводом дает материал для новой интерпретации и заслуживает отдельного рассмотрения. Нашей целью здесь было в основном показать возможные направление толкований этой проблемы, которая должна быть предметом дальнейших исследований.

\section{REFERENCES}

Bardaji, Anna Gil. Orero, Pilar. Esteva, Sara Rovira (Ed.). Translation Peripheries: Paratextual Elements in Translation. Frankfurt an Main: Peter Lang, 2012.

Belikov, Yegor. Masonyprotiv chekistov. Kniga, radi kotoroy „ubili” Pelevina. https://life.ru/p/902662 [Беликов, Егор, Масоны против чекистов. Книга, ради которой «убили» Пелевина https://life.ru/p/902662].

${ }^{29}$ Там же, с. 303. 
Buzadzhi, Dmitriy M. "Perevodchik prozrachnyy i neprozrachnyy." Mosty 2009, no. 2 (22) [Бузаджи, Дмитрий М. “Переводчик прозрачный и непрозрачный.” Мосты 2009, no. 2 (22)].

Gajda, Stanisław. "Społeczne determinacje nazw własnych tekstów (tytułów) Socjolingwistyka 1987 no. 6: 79-89.

Genette, Gérard. Paratexts: Tresholds of Interpretation. Tr. Lewin, Jane. Cambridge University Press, Cambridge 1997 [e-book 2001].

Genet, Gerard. "Posvyashcheniya”. Perevod, vstupitel'naya zametka i primechaniya L. Semenovoy. Ivanov, V.V. (Ed.), Antropologiya kul'tury. Vypusk 2, Moskva: Verdana, 2004 [Женетт Жерар. Посвящения. Перевод, вступительная заметка и примечания Л. Семеновой. Иванов. В.В. (Ed.). Антропология культуры. Выпуск 2. Москва: Вердана, 2004].

Hrehorowicz, Uta. "Przypisy tłumacza: to be or not to be." Filipowicz-Rudek, Maria; Konieczna-Twardzikowa, Jadwiga; Stoch, Marcin (Ed.). Między oryginałem a przekładem 3: Czy zawód thumacza jest $w$ pogardzie? Kraków: Universitas, 1997: 109-116.

Morozova, Olga. "Parateksty jako część strategii translatorskich Kseni Starosielskiej (na przykładzie 'Zdążyć przed Panem Bogiem' Hanny Krall).” Skibińska, Elżbieta (Ed.) Między oryginatem a przekładem XVII. Parateksty przekładu. Kraków: Universitas, 2011: 105-112.

Papadima, Maria. "Głos tłumacza w peritekście jego przekładu: przedmowa, posłowie, przypisy i inne zwierzenia.” Skibińska, Elżbieta (Ed.) Między oryginałem a przekładem XVII. Parateksty przekładu. Kraków: Universitas, 2011: $13-32$.

Paprocka, Natalia. "Elementy perytekstu nieautorskiego w polskich wydaniach 'Małego księcia.”' Między oryginałem a przekładem XVII. Parateksty przekładu. Skibińska, Elżbieta (Ed.) Między oryginatem a przekładem XVII. Parateksty przekładu. Kraków: Universitas, 2011: 113-136.

Pelevin, Victor. Generation “P”. Moskva: Vagrius, 2002 [Пелевин, Виктор. Generation “П”. Москва: Вагриус, 2002].

Pelevin V.: Rasskazy. Moskva: Vagrius 2001 [Пелевин, Виктор. Рассказы. Москва: Вагриус, 2001].

Pelevin, Viktor. Ananasnaya voda dlya prekrasnoy damy. Moskva: Eksmo 2010 [Пелевин, Виктор. Ананасная вода для прекрасной дамы. Москва: Эксмо. 2010].

Pelevin, Viktor. Betman Apollo. Moskva: Eksmo, 2013 [Пелевин, Виктор. Бэтман Аполло. Москва: Эксмо, 2013].

Pelevin, Viktor. Chapayev i pustota. Zheltaya strela. Moskva: Vagrius, 2001 [Пелевин, Виктор. Чапаев и пустота. Желтая стрела. Москва: Вагриус, 2001].

Pelevin, Viktor. Empire V. Povest'o nastoyashchem sverkhcheloveke. Moskva: Eksто 2012 [Пелевин,Виктор. Eтріге V. Повесть о настоящем сверхчеловеке. Москва: Эксмо. 2012].

Pelevin, Viktor. Lyubov' $k$ trëm tsukerbrinam. Moskva: Eksmo, 2014 [Пелевин, Виктор. Любовь к трем цукербринам. Москва: Эксмо, 2014].

Pelevin, Viktor. S.N.U.F.F. Moskva: Eksmo, 2013 [Пелевин, Виктор. S.N.U.F.F. Москва: Эксмо, 2018].

Pielewin Wiktor. Generation „P”. Transl. Rojewska-Olejarczuk, Ewa. Warszawa: W.A.B., 2002. 


\section{ПАРАТЕКСТЫ АВТОРА И ПЕРЕВОДЧИКА...}

Pielewin, Wiktor: Kryształowy świat. Transl. Rojewska-Olejarczuk, Ewa. Warszawa: W.A.B., 2008.

Pielewin, Wiktor: Miłość do trzech Zuckerbrinów. Transl. Janowski, Aleksander, Konin: Psychoskok, 2017.

Pielewin, Wiktor: Napój ananasowy dla pięknej damy. Transl. Rojewska-Olejarczuk, Ewa. Warszawa: W.A.B., 2011.

Pielewin,Wiktor. Batman Apollo. Transl. Rojewska-Olejarczuk, Ewa. Warszawa Warszawa: Wydawnictwo Literackie, 2014.

Pielewin,Wiktor. Mały palec Buddy. Transl. Broniatowska, Henryka. Warszawa: W.A.B, 2007.

Pielewin, Wiktor. Omon Ra i inne opowieści. Transl. Rojewska-Olejarczuk, Ewa. Warszawa: W.A.B., 2007.

Pielewin,Wiktor. S.N.U.F.F. Konin: Psychoskok, 2018.

Skibińska, Elżbieta. "O przypisach tłumacza: wprowadzenie do lektury.” Skibińska, Elżbieta (Ed.) Przypisy thumacza. Wrocław-Kraków 2009: 7-19.

Venuti, Lawrence. The Translator's Invisibility. A history of Translation. LondonNew York: Routledge, 1995.

Genet, Gerard. "Posvyashcheniya”. Perevod, vstupitel'naya zametka i primechaniya L. Semenovoy. Ivanov, V.V. (Ed.), Antropologiya kul'tury. Vypusk 2, Moskva: Verdana, 2004 [Женетт, Жерар. Посвящения. Перевод, вступительная заметка и примечания Л. Семеновой. Иванов. В.В. (Ed.). Антропология культуры. Выпуск 2. Москва: Вердана, 2004]. 